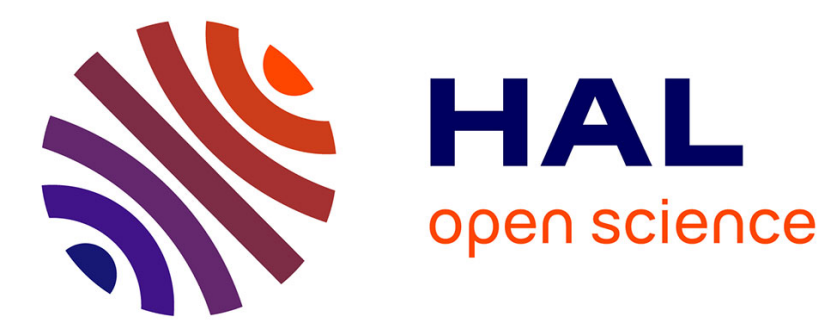

\title{
Co-receptor switch during HAART is independent of virological success
}

\author{
Annalisa Saracino, Laura Monno, Donatella C Cibelli, Grazia Punzi, Gaetano \\ Brindicci, Nicoletta Ladisa, Alessandra Tartaglia, Antonella Lagioia, \\ Gioacchino Angarano
}

\section{To cite this version:}

Annalisa Saracino, Laura Monno, Donatella C Cibelli, Grazia Punzi, Gaetano Brindicci, et al.. Coreceptor switch during HAART is independent of virological success. Journal of Medical Virology, 2009, 81 (12), pp.2036. 10.1002/jmv.21598 . hal-00531822

\section{HAL Id: hal-00531822 \\ https://hal.science/hal-00531822}

Submitted on 4 Nov 2010

HAL is a multi-disciplinary open access archive for the deposit and dissemination of scientific research documents, whether they are published or not. The documents may come from teaching and research institutions in France or abroad, or from public or private research centers.
L'archive ouverte pluridisciplinaire HAL, est destinée au dépôt et à la diffusion de documents scientifiques de niveau recherche, publiés ou non, émanant des établissements d'enseignement et de recherche français ou étrangers, des laboratoires publics ou privés. 


\section{Journal of Medical Virology}

WILEY

\section{Co-receptor switch during HAART is independent of virological success}

\begin{tabular}{|c|c|}
\hline Journal: & Journal of Medical Virology \\
\hline Manuscript ID: & JMV-09-1289.R1 \\
\hline Wiley - Manuscript type: & Research Article \\
\hline $\begin{array}{r}\text { Date Submitted by the } \\
\text { Author: }\end{array}$ & 04-Jun-2009 \\
\hline Complete List of Authors: & $\begin{array}{l}\text { Saracino, Annalisa; University of Foggia, Clinic of Infectious } \\
\text { Diseases } \\
\text { Monno, Laura; University of Bari, Clinic of Infectious Diseases } \\
\text { Cibelli, Donatella; University of Foggia, Clinic of Infectious Diseases } \\
\text { Punzi, Grazia; University of Bari, Clinic of Infectious Diseases } \\
\text { Brindicci, Gaetano; University of Bari, Clinic of Infectious Diseases } \\
\text { Ladisa, Nicoletta; University of Bari, Clinic of Infectious Diseases } \\
\text { Tartaglia, Alessandra; University of Foggia, Clinic of Infectious } \\
\text { Diseases } \\
\text { Lagioia, Antonella; University of Bari, Clinic of Infectious Diseases } \\
\text { Angarano, Gioacchino; University of Foggia, Clinic of Infectious } \\
\text { Diseases }\end{array}$ \\
\hline Keywords: & HIV-1, biological phenotype, env V3 loop, co-receptor \\
\hline
\end{tabular}

\section{scholarONE \\ Manuscript Central}


Table I. Shift of V3 genotype and MT-2 phenotype according to viro-immunological response to HAART.

\begin{tabular}{|c|c|c|c|c|c|c|c|c|c|c|c|c|}
\hline \multirow[b]{2}{*}{ Pt } & \multicolumn{6}{|c|}{ Baseline patient characteristics } & \multirow[b]{2}{*}{ New HAART regimen } & \multicolumn{2}{|c|}{$\begin{array}{c}\text { Virological and immunological } \\
\text { outcome }\end{array}$} & \multicolumn{3}{|c|}{ Co-receptor Shift } \\
\hline & $\begin{array}{l}\text { MT-2 } \\
\text { isolate }\end{array}$ & $\begin{array}{l}\text { RNA } \\
\text { V3 }\end{array}$ & $\begin{array}{l}\text { DNA } \\
\text { V3 }\end{array}$ & $\begin{array}{l}\text { Baseline } \\
\text { CD4 }\end{array}$ & $\begin{array}{c}\text { Baseline } \\
\text { pVL }\end{array}$ & $\begin{array}{l}\text { Antiretroviral } \\
\text { Therapy }\end{array}$ & & F-up CD4 & F_up pVL & $\begin{array}{c}\text { MT-2 } \\
\text { isolate }\end{array}$ & $\begin{array}{l}\text { RNA } \\
\text { V3 }\end{array}$ & $\begin{array}{c}\text { DNA } \\
\text { V3 }\end{array}$ \\
\hline \multicolumn{13}{|c|}{ Naive patients } \\
\hline 1 & $\mathrm{SI}$ & R5 & $\mathrm{X} 4$ & $48(6 \%)$ & 5,56 & none & $\mathrm{EFV}+\mathrm{AZT}+3 \mathrm{TC}$ & $169(19 \%)$ & 1,7 & - & _ & $\mathrm{X} 4 \rightarrow \mathrm{R} 5$ \\
\hline 2 & $\mathrm{SI}$ & R5 & $\mathrm{X} 4$ & $9(1 \%)$ & 5,07 & none & $\mathrm{LPV} / \mathrm{r}+\mathrm{TDF}+3 \mathrm{TC}$ & $198(13 \%)$ & 1,7 & - & - & $\mathrm{X} 4 \rightarrow \mathrm{R} 5$ \\
\hline 3 & NSI & $\mathrm{X} 4 / \mathrm{R} 5$ & X4 & $94(4 \%)$ & 2,66 & none & $\mathrm{LPV} / \mathrm{r}+\mathrm{TDF}+3 \mathrm{TC}$ & $104(6 \%)$ & 1,7 & - & - & $\mathrm{X} 4 \rightarrow \mathrm{R} 5$ \\
\hline 4 & $\mathrm{NSI}$ & R5 & $\mathrm{X} 4 / \mathrm{R} 5$ & $590(24 \%)$ & 5,14 & none & $\mathrm{LPV} / \mathrm{r}+\mathrm{TDF} / \mathrm{FTC}+\mathrm{T}-20$ & $633(24 \%)$ & 1,7 & - & - & $\mathrm{X} 4 / \mathrm{R} 5 \rightarrow \mathrm{R} 5$ \\
\hline 5 & NSI & R5 & R5 & $3(1 \%)$ & 5,00 & none & $\mathrm{LPV} / \mathrm{r}+\mathrm{TDF} / \mathrm{FTC}$ & $170(10 \%)$ & 1,7 & - & - & $\mathrm{R} 5 \rightarrow \mathrm{X} 4$ \\
\hline 6 & NSI & $\mathrm{R} 5$ & R5 & $15(3 \%)$ & 5,32 & none & $\mathrm{EFV}+\mathrm{ABC} / 3 \mathrm{TC}$ & $112(8 \%)$ & 1,7 & - & - & $\mathrm{R} 5 \rightarrow \mathrm{X} 4$ \\
\hline 7 & NSI & $X 4$ & R5 & $22(4 \%)$ & 4,60 & none & $\mathrm{LPV} / \mathrm{r}+\mathrm{ABC} / 3 \mathrm{TC}$ & $369(16 \%)$ & 1,7 & - & - & no \\
\hline 8 & NSI & $\mathrm{R} 5$ & $\mathrm{R} 5$ & $72(12 \%)$ & 4,54 & none & $\mathrm{LPV} / \mathrm{r}+\mathrm{ABC} / 3 \mathrm{TC}$ & $395(26 \%)$ & 1,7 & - & - & no \\
\hline 9 & NSI & $\mathrm{R} 5$ & R5 & $73(6 \%)$ & 4,68 & none & $\mathrm{LPV} / \mathrm{r}+\mathrm{TDF} / \mathrm{FTC}$ & $341(11 \%)$ & 1,7 & - & - & no \\
\hline 10 & NSI & $\mathrm{R} 5$ & $\mathrm{X} 4 / \mathrm{R} 5$ & $13(3 \%)$ & 5,25 & none & $L P V / r+A B C / 3 T C$ & $364(12 \%)$ & 1,7 & - & - & no \\
\hline 11 & NSI & R5 & R5 & $392(24 \%)$ & 4,90 & none & $\mathrm{LPV} / \mathrm{r}+\mathrm{ABC} / 3 \mathrm{TC}$ & $484(29 \%)$ & 1,7 & - & - & no \\
\hline 12 & NSI & $\mathrm{R} 5$ & $X 4$ & $97(10 \%)$ & 6,27 & none & $\mathrm{LPV} / \mathrm{r}+\mathrm{TDF}+3 \mathrm{TC}$ & $172(16 \%)$ & 2,7 & - & - & no \\
\hline 13 & NSI & $\mathrm{R} 5$ & R5 & $354(23 \%)$ & 4,75 & none & $\mathrm{f}-\mathrm{APV} / \mathrm{r}+\mathrm{TDF} / \mathrm{FTC}$ & $290(26 \%)$ & 1,7 & - & - & no \\
\hline 14 & NSI & $\mathrm{X} 4$ & $\mathrm{R} 5$ & 0 & 6,46 & none & $\mathrm{LPV} / \mathrm{r}+\mathrm{ABC} / 3 \mathrm{TC}$ & $43(2 \%)$ & 1,7 & - & - & no \\
\hline 15 & NSI & $\mathrm{R} 5$ & $\mathrm{R} 5$ & $141(13 \%)$ & 5,49 & none & $\mathrm{LPV} / \mathrm{r}+\mathrm{ABC} / 3 \mathrm{TC}$ & $227(13 \%)$ & 3,8 & - & - & no \\
\hline 16 & NSI & $\mathrm{R} 5$ & $\mathrm{R} 5$ & $101(14 \%)$ & 6,57 & none & $\mathrm{LPV} / \mathrm{r}+\mathrm{TDF} / \mathrm{FTC}$ & $531(23 \%)$ & 3,1 & - & - & no \\
\hline 17 & NSI & $\mathrm{R} 5$ & $\mathrm{R} 5$ & $367(20 \%)$ & 4,64 & none & $\mathrm{LPV} / \mathrm{r}+\mathrm{TDF} / \mathrm{FTC}$ & $617(32 \%)$ & 1,7 & - & - & no \\
\hline 18 & NSI & R5 & R5 & $247(26 \%)$ & 5,04 & none & $f-A P V / r+A B C / 3 T C$ & $541(30 \%)$ & 1,7 & - & - & no \\
\hline \multicolumn{13}{|c|}{ Antiretroviral experienced patients } \\
\hline \multicolumn{13}{|c|}{ Responders } \\
\hline 19 & NSI & $\mathrm{R} 5$ & $\mathrm{X} 4$ & $161(12 \%)$ & 5,77 & $\mathrm{LPV} / \mathrm{r}+\mathrm{TDF}+3 \mathrm{TC}$ & $\mathrm{TPV} / \mathrm{r}+\mathrm{EFV}+\mathrm{TDF}+3 \mathrm{TC}$ & $323(19 \%)$ & 1,7 & _ & _- & $\mathrm{X} 4 \rightarrow \mathrm{R} 5$ \\
\hline 20 & NSI & $\mathrm{R} 5$ & $\mathrm{R} 5$ & $72(15 \%)$ & 6,38 & $\mathrm{LPV} / \mathrm{r}+\mathrm{TDF}+3 \mathrm{TC}$ & $T P V / r+T D F+3 T C+T-20$ & $273(21 \%)$ & 1,7 & - & - & $\mathrm{R} 5 \rightarrow \mathrm{X} 4$ \\
\hline 21 & NSI & R5 & R5 & $264(30 \%)$ & 4,80 & $\mathrm{f}-\mathrm{APV} / \mathrm{r}+\mathrm{DDI}+\mathrm{TDF}+3 \mathrm{TC}$ & $\mathrm{TPV} / \mathrm{r}+\mathrm{TDF}+3 \mathrm{TC}+\mathrm{T}-20$ & $459(34 \%)$ & 1,7 & - & - & $\mathrm{R} 5 \rightarrow \mathrm{X} 4$ \\
\hline 22 & NSI & $\mathrm{R} 5$ & $\mathrm{R} 5$ & $562(29 \%)$ & 3,27 & $\mathrm{LPV} / \mathrm{r}+\mathrm{D} 4 \mathrm{~T}+3 \mathrm{TC}$ & $\mathrm{TPV} / \mathrm{r}+3 \mathrm{TC}+\mathrm{EFV}$ & $603(32 \%)$ & 1,7 & - & - & no \\
\hline 23 & NSI & R5 & R5 & $194(11 \%)$ & 4,39 & $\mathrm{EFV}+\mathrm{TDF}+3 \mathrm{TC}$ & $\mathrm{TPV} / \mathrm{r}+\mathrm{TDF}+3 \mathrm{TC}+\mathrm{T}-20$ & $324(18 \%)$ & 1,7 & - & - & no \\
\hline 24 & NSI & $X 4$ & $X 4$ & $65(8 \%)$ & 4,46 & $\mathrm{LPV} / \mathrm{r}+\mathrm{TDF}+3 \mathrm{TC}$ & $\mathrm{TPV} / \mathrm{r}+\mathrm{TDF}+3 \mathrm{TC}+\mathrm{T}-20$ & $224(14 \%)$ & 1,7 & - & - & no \\
\hline 25 & NSI & R5 & $\mathrm{R} 5$ & $468(18 \%)$ & 5,11 & $\mathrm{LPV} / \mathrm{r}+\mathrm{AZT}+3 \mathrm{TC}$ & $\mathrm{TPV} / \mathrm{r}+\mathrm{TDF}+3 \mathrm{TC}+\mathrm{T}-20$ & $367(20 \%)$ & 1,7 & - & - & no \\
\hline 26 & NSI & $X 4$ & $X 4$ & $235(7 \%)$ & 5,00 & $\mathrm{LPV} / \mathrm{r}+3 \mathrm{TC}+\mathrm{TDF}$ & $\mathrm{TPV} / \mathrm{r}+\mathrm{EFV}+3 \mathrm{TC}$ & $295(8 \%)$ & 1,7 & - & - & no \\
\hline 27 & NSI & $\mathrm{X} 4$ & X4 & $311(17 \%)$ & 4,36 & $\mathrm{SQV} / \mathrm{r}+\mathrm{AZT} / 3 \mathrm{TC}$ & $\mathrm{TPV} / \mathrm{r}+\mathrm{TDF}+3 \mathrm{TC}+\mathrm{T}-20$ & $470(16 \%)$ & 1,7 & - & - & no \\
\hline \multicolumn{13}{|c|}{ Non responders } \\
\hline 28 & $\mathrm{SI}$ & $X 4$ & $\mathrm{X} 4$ & $27(3 \%)$ & 4,54 & $\mathrm{LPV} / \mathrm{r}+\mathrm{TDF}+3 \mathrm{TC}$ & $\mathrm{TPV} / \mathrm{r}+\mathrm{EFV}+\mathrm{TDF} / \mathrm{FTC}$ & $22(2 \%)$ & 5,30 & $\mathrm{SI} \rightarrow \mathrm{NSI}$ & no & $\mathrm{X} 4 \rightarrow \mathrm{R} 5$ \\
\hline 29 & SI & R5 & $\mathrm{R} 5$ & $30(5 \%)$ & 5,84 & $\mathrm{ATV} / \mathrm{r}+\mathrm{TDF}+3 \mathrm{TC}+\mathrm{T}-20$ & $T P V / r+T D F+3 T C+T-20$ & $77(7 \%)$ & 5,34 & $\mathrm{SI} \rightarrow \mathrm{NSI}$ & no & no \\
\hline
\end{tabular}




\begin{tabular}{|c|c|c|c|c|c|c|c|c|c|c|c|c|}
\hline 30 & SI & R5 & R5 & $90(6 \%)$ & 2,90 & $\mathrm{LPV} / \mathrm{r}+\mathrm{TDF}+\mathrm{ABC}+3 \mathrm{TC}$ & $T P V / r+T D F+A B C+3 T C$ & $122(8 \%)$ & 4,57 & no & no & no \\
\hline 31 & NSI & R5 & R5 & $143(20 \%)$ & 4,44 & $f-A P V+R T V+A B C+3 T C$ & $\mathrm{TPV} / \mathrm{r}+\mathrm{ABC} / 3 \mathrm{TC}+\mathrm{T}-20$ & $178(14 \%)$ & 3,36 & no & no & no \\
\hline 32 & $\mathrm{NSI}$ & R5 & R5 & $170(25 \%)$ & 4,71 & $\mathrm{LPV} / \mathrm{r}+\mathrm{TDF}+3 \mathrm{TC}$ & $T P V / r+T D F+3 T C+T-20$ & $172(21 \%)$ & 5,11 & no & no & no \\
\hline 33 & NSI & $\mathrm{X} 4$ & R5 & $123(5 \%)$ & 4,79 & $L P V / r+T D F+3 T C$ & $\mathrm{TPV} / \mathrm{r}+\mathrm{ABC} / 3 \mathrm{TC}+\mathrm{EFV}$ & $202(6 \%)$ & 4,04 & no & no & no \\
\hline 34 & NSI & R5 & R5 & $145(7 \%)$ & 5,27 & APV/r+NVF+DDI & $\mathrm{TPV} / \mathrm{r}+\mathrm{TDF}+3 \mathrm{TC}$ & $118(7 \%)$ & 5,63 & no & no & no \\
\hline 35 & NSI & R5 & R5 & $50(17 \%)$ & 6,48 & $\mathrm{ATV} / \mathrm{r}+\mathrm{DDI}+\mathrm{T}-20$ & TPV/r+3TC+T-20 & $196(15 \%)$ & 5,08 & no & no & no \\
\hline 36 & $\mathrm{NSI}$ & $\mathrm{X} 4$ & R5 & $27(2 \%)$ & 5,41 & LPV/r +TDF+3TC & $T P V / r+T D F+3 T C+T-20$ & $97(4 \%)$ & 4,88 & no & $\mathrm{X} 4 \rightarrow \mathrm{R} 5$ & no \\
\hline
\end{tabular}

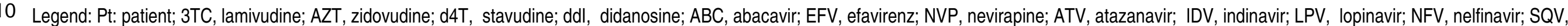

11 saquinavir; TPV, tipranavir; f-APV, fosaamprenavir; T-20, enfuvirtide; pVL: plasma viral load; F-up: Follow-up. 
Table II. Correlation of baseline patient characteristics with the occurrence of a tropism shift in proviral DNA after one year of antiretroviral therapy.

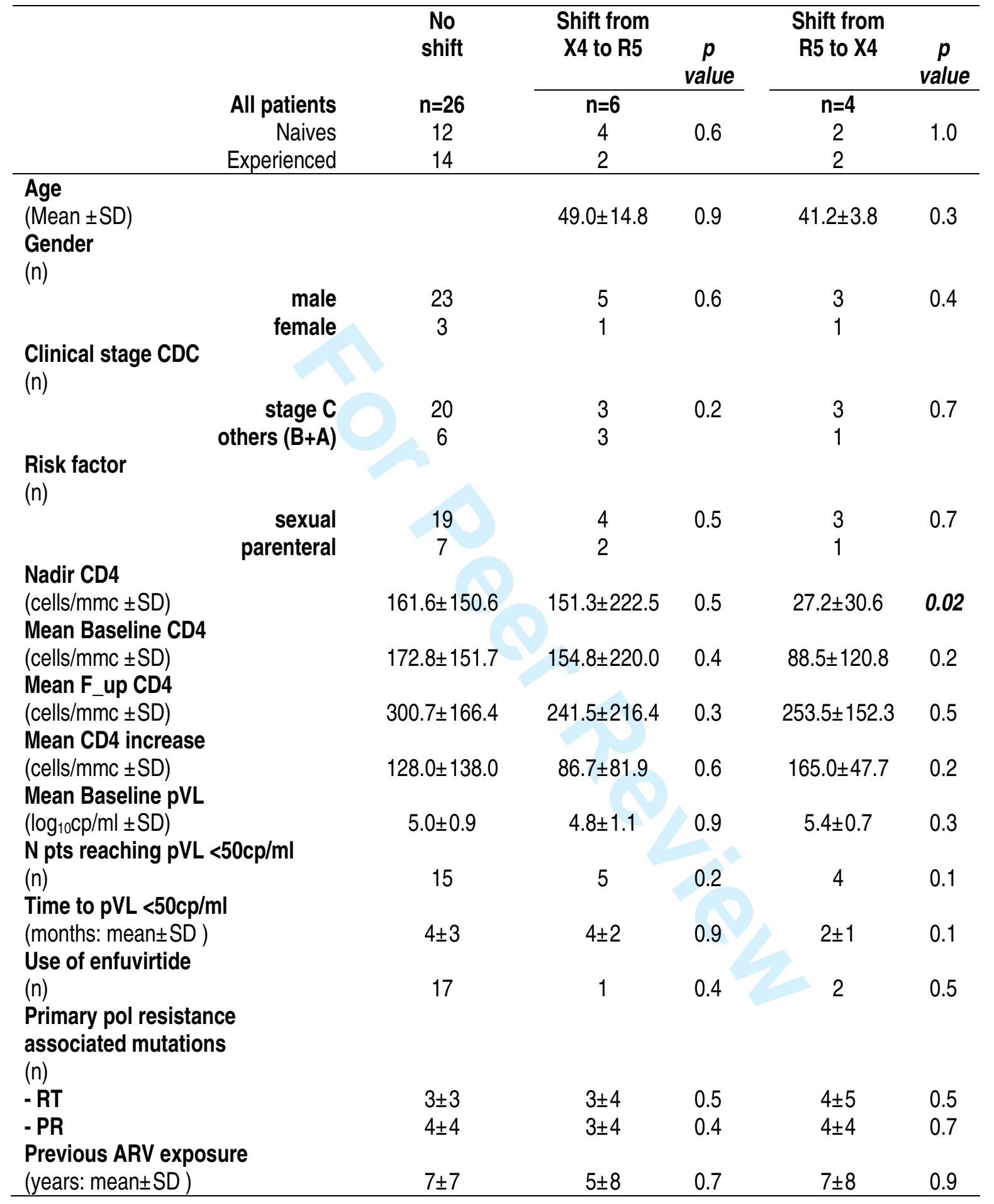

Legend: N: number; SD: standard deviation; CDC: Center for Diseases Control; F-up: Follow-up; pVL: plasma viral load; RT: reverse transcriptase; PR: protease; ARV: antiretroviral therapy 
Figure 1. Serial V3 loop sequences of patients changing their V3 genotype during HAART.

\begin{tabular}{|c|c|c|c|c|c|c|c|c|c|c|c|c|c|c|c|c|c|c|c|c|c|c|c|c|c|c|c|c|c|c|c|c|c|c|c|c|c|c|c|c|c|c|c|}
\hline \multirow[t]{2}{*}{$\mathrm{Pt}$} & \multirow{2}{*}{$\begin{array}{c}\text { Source } \\
\mathrm{H} \times \mathrm{B} 2\end{array}$} & \multicolumn{39}{|c|}{ V3 aminoacidic sequence } & \multirow[t]{2}{*}{$\mathrm{n}$} & \multirow[t]{2}{*}{ NC } & \multirow[t]{2}{*}{ PSSM } \\
\hline & & C & $T$ & $\mathbf{R}$ & $\mathbf{P}$ & $\mathbf{N}$ & $\mathbf{N}$ & $\mathrm{N}$ & $\begin{array}{ccc}T \\
\end{array}$ & $\mathbf{R}$ & $\mathrm{K}$ & $\mathbf{R}$ & $\mathrm{I}$ & $\mathbf{R}$ & $\mathrm{I}$ & $\mathbf{Q}$ & $\mathbf{R}$ & $\mathbf{G}$ & $\mathbf{P}$ & G & $\mathbf{R}$ & A & $\mathbf{F}$ & $\mathrm{V}$ & $T$ & $\mathrm{I}$ & & & $\mathbf{G}$ & $\mathrm{K}$ & & $\mathrm{I}$ & G & $\mathrm{N}$ & $M$ & $\mathbf{R}$ & $\mathbf{Q}$ & A & $\mathrm{H}$ & C & & & \\
\hline \multirow[t]{3}{*}{1.} & RNA bl & . & & . & . & & . & . & . & . & . & $\mathbf{S}$ & . & $\mathrm{H}$ & $\mathrm{M}$ & - & _- & . & . & . & & . & & $\mathrm{Y}$ & A & $\mathrm{T}$ & _- & _- & & D & 1 & & . & D & 1 & & $\mathrm{~K}$ & & . & . & 35 & 6 & R5 \\
\hline & DNA bl & . & & . & . & $\mathrm{s}$ & . & . & . & . & . & G & & & . & - & _- & . & . & . & & . & V & $\mathrm{Y}$ & A & $\mathrm{T}$ & - & - & $\mathrm{E}$ & $\mathbf{R}$ & 1 & V & . & & I & & . & & . & . & 35 & 7 & $\mathrm{X} 4$ \\
\hline & DNA fu & & & . & . & $\mathrm{s}$ & . & & . & . & . & G & V & $\mathrm{H}$ & . & - & - & . & . & . & & . & L & $\mathrm{F}$ & $\mathrm{R}$ & & 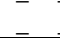 & 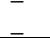 & $T$ & $S$ & I & $\mathrm{T}$ & . & D & I & & . & & . & . & 34 & 7 & R5 \\
\hline \multirow[t]{3}{*}{2.} & RNA bl & & & . & . & & . & & . & . & . & $\mathrm{s}$ & . & $\mathrm{P} / \mathrm{S} / \mathrm{R} / \mathrm{C}$ & . & 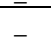 & 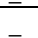 & . & & . & & . & & $\mathrm{F}$ & $A$ & $\overline{\mathrm{T}}$ & - & 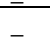 & $G$ & $D / G$ & $\mathrm{I}$ & & . & $\mathrm{D}$ & 1 & & . & & . & . & 35 & $4-6$ & R5 \\
\hline & DNA bl & . & & . & . & & . & . & . & . & . & G & . & & . & - & _- & . & . & . & & . & V & I & A & $\mathrm{T}$ & - & - & $E$ & $\mathrm{~K}$ & I & & . & o & I & & . & & . & . & 35 & 7 & $\mathrm{X} 4$ \\
\hline & DNA fu & & & & & & & & & & & s & & $\dot{s}$ & & - & - & . & & & & & . & $\mathrm{V} / \mathrm{F}$ & A & $\mathrm{T}$ & - & $\begin{array}{lll}- & \end{array}$ & $G$ & D & I & & & D & I & & & & $\dot{Y}$ & & 35 & 3 & R5 \\
\hline \multirow[t]{3}{*}{3.} & RNA bl & & & . & . & & . & & . & . & . & $S$ & & $T$ & . & - & - & . & & . & & V & . & $\mathrm{D}$ & A & $T$ & - & - & - & D & 1 & & . & $\mathrm{D}$ & 1 & & $\mathrm{~K} / \mathrm{Q}$ & & $Y$ & . & 34 & $2-3$ & $\mathrm{X} 4 / \mathrm{R} 5$ \\
\hline & DNA bl & & & . & . & & . & . & . & & & S & & $\mathrm{T}$ & & - & - & . & . & . & & V & . & D & A & $\mathrm{T}$ & - & - & - & D & I & & . & D & I & & K & & $Y$ & . & 34 & 3 & X4 \\
\hline & DNA fu & & & . & & & & & . & I & $\mathrm{R}$ & $S$ & . & $\mathrm{H}$ & M & & & . & & . & & & . & $\mathrm{T}$ & & $\mathrm{T}$ & & & & D & I & & . & $\mathrm{D}$ & i & & $\mathrm{K}$ & & & . & 35 & 5 & R5 \\
\hline \multirow[t]{3}{*}{4.} & RNA bl & & & . & . & & . & . & . & . & . & $S$ &. & $P$ & $M$ & - & _ & . & . & . & & & . & $Y$ & . & $T$ & - & & . & $Q$ & I & & . & $\mathrm{D}$ & 1 & & . & & $\mathrm{F}$ & . & 35 & 4 & R5 \\
\hline & DNA bl & & & . & . & & . & . & . & . & . & $R / S$ & & P & $\mathrm{I} / \mathrm{L}$ & - & - & . & . & . & & $\mathrm{A} / \mathrm{V}$ & . & $Y$ & . & $\mathrm{T}$ & - & - & . & $\mathbf{Q}$ & 1 & & . & D & I & & . & & $\mathrm{F}$ & . & 35 & $4-5$ & $X 4 / R 5$ \\
\hline & DNA fu & & & . & & & & & & & & $S$ & $\mathrm{I} / \mathrm{V}$ & P & $M$ & & & . & & & & & . & $Y$ & . & $\mathrm{T}$ & & & & $\hat{Q}$ & i & & . & D & I & & & & $\mathrm{F}$ & . & 35 & 4 & R5 \\
\hline \multirow[t]{3}{*}{5.} & RNA bl & . & & . & . & & . & . & . & . & $R$ & $S$ & . & $\mathrm{H}$ & . & 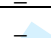 & - & . & . & . & & . & . & $Y$ & 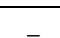 & 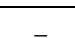 & - & $G$ & $T$ & D & $\mathrm{V}$ & & . & $\mathrm{D}$ & $\mathrm{I}$ & & . & & $Y$ & . & 34 & 4 & R5 \\
\hline & DNA bl & & & . & 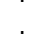 & & & & & . & & S & & $\mathrm{H}$ & & & & & . & . & & . & 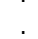 & $Y$ & & - & -1 & A & $\mathrm{T}$ & D & V & & . & D & i & & & & $Y$ & . & 34 & 4 & R5 \\
\hline & DNA fu & & & . & & S & K & $T$ & I & . & $\mathrm{R}$ & R & & $\mathrm{H}$ & . & 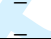 & I & 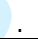 & & & & . & 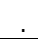 & $Y$ & $\vec{A}$ & $\overline{\mathrm{T}}$ & $\bar{D}$ & V & $\mathrm{T}$ & G & V & K & & D & I & & $\mathrm{R}$ & & $Y$ & & 37 & 7 & $\mathrm{X} 4$ \\
\hline 6. & RNA bl & & V & . & . & . & . & . & . & . & . & S & . & $\mathrm{H}$ & . & - & - & . & & . & & . & . & $\mathrm{Y}$ & - & - & - & - & . & $E$ & $\mathrm{I}$ & &. & $\mathrm{D}$ & 1 & & . & & . &. & 34 & 5 & R5 \\
\hline & DNA bl & & V & . & & & & & . & 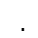 & . & S & & $\mathrm{H}$ & . & - & - & 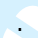 & & & & & & $Y$ & - & & - & - & & E & I & & . & D & I & & . & & . & . & 34 & 5 & R5 \\
\hline & DNA fu & & $\mathrm{T}$ & . & . & & . & & . & . & . & G & & & & & - & . & & & & . & $\mathrm{R}$ & $\mathrm{F}$ & Y & $\bar{A}$ & - & - & $T$ & $\bar{K}$ & i & & . & $\mathrm{D}$ & I & & . & & . & . & 35 & 7 & $\mathrm{X} 4$ \\
\hline 19. & RNA bl & & & . & . & $\mathrm{S}$ & . & & . & . & . & $\mathrm{s}$ & & $P$ & M & & & . & . & . & & & 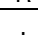 & $Y$ & & $T$ & & - & & D & & & . & . & 1 & & & & . & . & 35 & 5 & R5 \\
\hline & DNA bl & & & . & . & & . & & . & . & . & R & & $\mathrm{T}$ & $\mathrm{L}$ & - & _ & . & . & . & & V & $Y$ & $Y$ & . & $\mathrm{T}$ & - & & & $Q$ & I & & . & . & I & & $\mathrm{R}$ & & . & . & 35 & 7 & $\mathrm{X} 4$ \\
\hline & DNA fu & & & . & 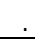 & $\mathrm{N} / \mathrm{s}$ & . & & . & & & $S$ & & $\mathrm{H} / \mathrm{P}$ & $1 / \mathrm{M}$ & - & - & . & & . & $\mathrm{K} / \mathrm{R}$ & & . & Y & & $\mathrm{T}$ & - & $\begin{array}{lll}- \\
\end{array}$ & & D & i & & . & 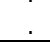 & I & & & & . & ${ }^{\circ}$ & 35 & $5-6$ & R5 \\
\hline 20. & RNA bl & & & . & . & & . & & . & . & $\mathrm{K} / \mathrm{R}$ & $\mathbf{G}$ & . & $\mathrm{N} / \mathrm{H} / \mathrm{S} / \mathrm{R}$ & . & - & & . & & . & & $\mathrm{A} / \mathrm{S}$ & & $\mathrm{N} / \mathrm{Y} / / \mathrm{F}$ & $A$ & $R / T$ & & 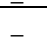 & $E / G / D$ & $\mathbf{R}$ & $\mathrm{I}$ & & & $\mathrm{D}$ & $\mathrm{I}$ & & . & & . & . & 35 & $6-7$ & R5 \\
\hline & DNA bl & & & . & . & & . & . & . & . & & S & & $P$ & & - & - & . & & . & & & & Y & & $\mathrm{T}$ & - & - & & D & I & & . & & I & & . & & . & . & 35 & 5 & R5 \\
\hline & DNA fu & & & & & & & & & & $\mathrm{R}$ & G & & $S$ & & & - & & & . & & S & & I & A & $\mathrm{R}$ & - & - & D & $\mathbf{R}$ & I & & & D & I & & & & . & & 35 & 6 & $\mathrm{X} 4$ \\
\hline 21. & RNA bl & & & $\mathrm{R} / \mathrm{T}$ & . & & . & . & . & . & . & $\mathrm{G}$ & . & $\mathrm{H}$ & & - & - & . & & . & & & V & $\mathrm{Y}$ & & A & & & $T$ & $Q$ & 1 & & & $\mathrm{D}$ & 1 & & . & & & & 35 & $5-6$ & R5 \\
\hline & DNA bl & & & . & & S & & & . & & . & G & & $\mathrm{H}$ & . & - & - & . & & . & & . & V & $Y$ & & A & - & - & $\mathrm{T}$ & $Q$ & I & & & D & I & & . & & . & . & 35 & 6 & R5 \\
\hline & DNA fu & & & & & $\mathrm{N} / \mathrm{S}$ & & & & & & $G$ & & $\mathrm{H}$ & & & & & & & & . & V & Y & & A & & & $\mathrm{T}$ & $\mathrm{K} / \mathrm{Q}$ & I & & & $\mathrm{D}$ & I & & & & & & 35 & $6-7$ & X4/R5 \\
\hline 28. & RNA bl & & & . & . & & $\mathrm{K} / \mathrm{D}$ & $\mathrm{K}$ & & & & $\mathbf{R}$ & & $Q$ & & & & & r & . & & & . & $\mathrm{V}$ & & & & & $T$ & D & & $Q$ & & $\mathrm{D}$ & $\mathrm{L}$ & & $\mathrm{L}$ & & $Y$ & . & 33 & $4-6$ & X4 \\
\hline & RNA fu & & & . & . & $\mathrm{Y}$ & $\mathrm{E}$ & $\mathrm{K}$ & . & K & R & $\mathrm{R}$ & & $\mathrm{K}$ & . & - & - & . & & . & & . & . & V & - & - & 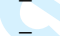 & & $\mathrm{T}$ & D & I & $\mathrm{K}$ & & D & L & & L & & Y & . & 33 & 6 & X4 \\
\hline & DNA bl & & & . & . & $\mathrm{Y}$ & $\mathrm{K}$ & $\mathrm{K}$ & . & $\mathrm{K}$ & $\mathrm{R}$ & R & & $Q$ & . & - & - & . & & . & & . & . & V & - & & - & & $\mathrm{T}$ & D & I & $Q$ & & D & $\mathrm{L}$ & & $\mathrm{L}$ & & $Y$ & & 33 & 6 & $\mathrm{X} 4$ \\
\hline & DNA fu & & & & & & & & & & $\mathrm{K} / \mathrm{R}$ & $S$ & & $\mathrm{H}$ & & & & . & & . & & . & & $Y$ & $T / A$ & $\overline{\mathrm{T}}$ & & & & $E / D$ & I & I & & D & I & & $\mathrm{Q} / \mathrm{R}$ & & & 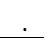 & 35 & 5 & R5 \\
\hline
\end{tabular}

Legend: Pt=Patient; $n$ : number of aminoacids (V3 sequence length); NC=net charge; PSSM (Position-Specific Scoring Matrix). Columns corresponding to positions 11 and 25 of the env $\mathrm{V} 3$ sequence are highlighted. 


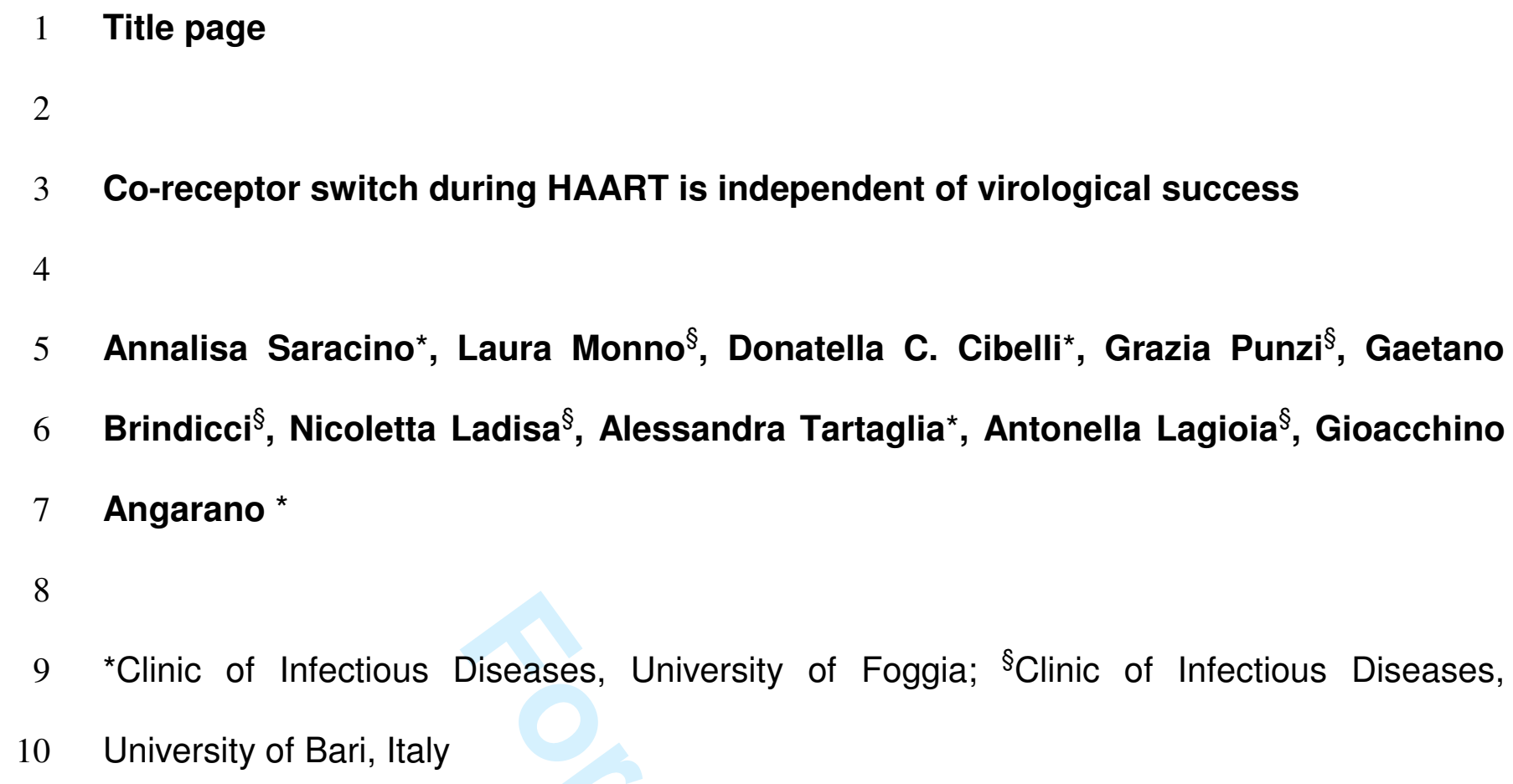




\section{ABSTRACT}

25 The influence of antiretroviral therapy on co-receptor tropism remains controversial. To 26 verify if co-receptor tropism shift was affected by HAART, the evolution of proviral DNA V3 27 genotype after 12 months of a new antiretroviral regimen was compared between 28 responder and non-responder patients.

29 Baseline blood samples were collected from 36 patients infected with HIV-1 subtype-B (18 30 naïve and 18 experienced) for virus isolation and env V3 genotyping from plasma HIV-1 31 RNA and PBMC DNA. DNA V3 genotyping was repeated after 12 months from initiating 32 HAART. WebPSSM was used for categorizing V3 sequences into X4 or R5; for analysis 33 purposes, dual/mixed viruses were considered as X4.

34 From the $10(28 \%)$ patients changing their proviral DNA V3 genotype during therapy, six 35 shifted from R5-to-X4 and four from X4-to-R5. The lack of reaching virological suppression 36 was not associated with an $\mathrm{X} 4-$ to- $\mathrm{R} 5(\mathrm{p}=0.25)$ or $\mathrm{R} 5$-to-X4 $(\mathrm{p}=0.14)$ shift; time-to-viral 37 suppression and CD4 increase were similar in both groups. No association was found 38 between tropism shift and patient baseline characteristics including age, sex, CDC stage, 39 CD4 count, viral load, exposure and length of previous HAART, enfuvirtide use in the new 40 regimen, number of reverse-transcriptase and protease resistance-associated mutations. 41 Conversely, CD4 nadir was correlated to emergence of X4 virus in proviral DNA (mean $4227.2 \pm 30.6$ in R5-to-X4 shifting patients vs $161.6 \pm 150.6$ in non-shifting patients, $p=0.02)$.

43 The occurrence of a tropism shift in both directions was independent of HAART use, 44 irrespective of its efficacy. The CD4 count nadir was the only baseline characteristic able 45 to predict an R5-to-X4 viral shift. 
46 KEY WORDS: HIV-1, biological phenotype, env V3 loop, co-receptor

3
4
5
6
7
8
9
10

11

12

13

14

15

16

17

18

19

20

21

22

23

24

25

26

27

28

29

30

31

32

33

34

35

36

37

38

39

40

41

42

43

44

45

46

47

48

49

50

51

52

53

54

55

56

57

58

59

60 


\section{INTRODUCTION}

The third variable (V3) region of the HIV-1 gp120 envelope is known to be responsible for viral tropism. Specific amino acid variations in the V3 loop, especially the distribution of charged amino acids, have been correlated with the type of co-receptor used by HIV-1 [de Jong et al., 1992; Fouchier et, al. 1995]. Together with CD4, two different chemokine receptors (CXCR4 and CCR5) are employed mainly by the virus for entry into cells and therefore, HIV-1 variants can be distinguished into X4 and R5 variants [Deng et al., 1996]; dual/tropic strains and/or mixture of the two variants have also been described (D/M or X4/R5 viruses). The use of co-receptor can be tested by adopting different cell lines, each expressing one of the two co-receptors; one commercial recombinant phenotype assay (Trofile ${ }^{\mathrm{TM}}$ Monogram Biosciences, San Francisco, CA, USA) [Whitcomb et al., 2007] and some in-house methods are available. This classification has replaced the previous distinction of viral isolates on MT-2 cells as syncytium inducing (SI) and non-syncytium inducing (NSI) [Schuitemaker $\mathrm{H}$ et al., 1991] since MT-2 cells are exclusively permissive to infection by SI viruses because they only express CXCR4 on al., 2008, Raymond et al., 2008; Poveda et al., 2009; Chueca et al., 2009]. Easier and less expensive methods for determining the co-receptor tropism of HIV are required, as they are no longer used exclusively for research but have entered into clinical practice, given the development of new chemokine-co-receptor inhibitors.

72 CXCR4, which target preferentially naïve and resting CD4 ${ }^{+}$T-lymphocytes and have an 
73 higher replication rate than R5 variants, emerge in approximately $40-50 \%$ of infected 74 persons over the course of disease [Berger et al., 1999]. However, whether these X4 75 isolates arise as a consequence of the loss of $\mathrm{CD} 4^{+}$cells, or precede it (in which case they 76 might be involved causally in $\mathrm{CD}^{+}$cell depletion), is still debated. Moreover, it is not

80 Previous studies based on HIV-1 isolation in MT-2 cells have correlated the presence of 81 SI variants to a worse clinical outcome in terms of CD4 decrease, viral load, disease stage known if the presence of $\mathrm{X} 4$ viruses, which affect immune progenitor cells at the thymus level, might cause an impairment of CD4 reconstitution even during HAART [Moore et al., 2004; Delobel et al., 2006]. and mortality [Berger et al., 1999; Connor, HO 1994; Karlsson et al., 1994; Maas et al., 2000; de Roda et al., 1997]. Also studies based on V3 genotype [Brumme et al., 2004] or phenotype [Daar et al., 2007, Waters et al., 2008] agree that the use of the X4 co-receptor is associated with a more rapid HIV-1 disease progression, while results regarding the response to HAART are equivocal; some authors [Brumme et al., 2004] have found that response to antiretroviral therapy is diminished in patients harbouring a X4 rather than a R5 variant, whereas other studies exclude the direct effect of co-receptor tropism on therapy response [Waters et al., 2008].

On the other hand, the influence of HAART on tropism shift is unclear. It has been hypothesized that antiretroviral therapy might exert a different selective pressure on $\mathrm{X} 4$ or R5 variants in the viral population. Some studies reported a preferential suppression of X4 viruses with HAART [Philpott et al., 2001; Equils et al., 2000, Skrabal et al., 2003, Galan et al., 2004] while other studies suggested a predominant R5 to X4 switch in cell reservoirs with effective therapy [Johnston et al., 2003, Delobel et al., 2005]. More recently, a greater overall prevalence of X4 viruses was observed in experienced-patient cohorts [Melby et al., 2006; Wilkin et al., 2007; Hunt et al., 2006; Coakley et al., 2006] when compared to 
98 naïve patients [Brumme et al., 2005; Moyle et al., 2005 ; Demarest et al., 2004; Coakley et 99 al., 2006; Poveda et al., 2007].

100 The use of co-receptors is now mandatory for patients who are candidates to receive an anti-CCR5 inhibitor, but viral tropism shifts between the time of testing and start of therapy have been described [Fätkenheuer et al., 2008]. Whether some patient characteristics might be predictive of tropism shift is still unknown; their identification would certainly help to better define therapeutic strategies including virus entry inhibitors. Therefore, the aim of the present study was to compare the $\mathrm{V} 3$ genotype at baseline and after initiating a new antiretroviral therapy in two groups of patients (naïve and experienced) according to their response to a new HAART regimen. 


\section{PATIENTS AND METHODS}

\section{Patients}

A total of 36 patients infected with HIV were enrolled in the study, including 18 antiretroviral-naïve patients and 18 patients failing HAART, whose clinical, virological and immunological characteristics are shown in Table I.

Naïve patients were enrolled consecutively from newly diagnosed patients requiring antiretroviral therapy; all were diagnosed with advanced stage of disease (CD4 cell count $<350$ cells $/ \mathrm{mmc}$ ) with the exception of patients $4,11,13$ and 17 who, despite of an high absolute number of CD4 cells/mmc, required treatment with HAART due to presence of clinical symptoms.

Antiretroviral-experienced patients were enrolled from those participating in an expanded access program for a new antiretroviral drug (tipranavir) and, according to the protocol inclusion criteria, had been treated previously with all three antiretroviral classes including at least two PI-based regimens. Blood samples from all patients were collected at baseline (from a few days up to two weeks before starting or changing the antiretroviral regimen) for virus isolation and genotyping of the env $\mathrm{V} 3$ region on plasma RNA and PBMC DNA.

Patients were followed monthly for virological and immunological parameters and clinical evolution; for patients achieving virological success (HIV-RNA $<50 \mathrm{cp} / \mathrm{ml}$ ), V3 genotyping was determined on PBMC DNA 12 months after initiating HAART while for patients who did not response to therapy and remained viremic, virus isolation and genotyping of the env $\mathrm{V} 3$ region were determined on both plasma RNA and PBMC DNA 12 months after initiating HAART. 


\section{METHODS}

Phylogenetic analysis of $\mathrm{pol}$ and env gene sequences (neighbor-joining method using Kimura two-parameter distances) from these patients was performed to confirm that all enrolled patients were infected with a subtype B HIV-1.

Plasma HIV-RNA was assessed using a NASBA real time PCR (Nuclisens Easy-Q HIV-1, Biomérieux, Boseind, France) with a lower detection limit of 50 copies $/ \mathrm{ml}$.

Peripheral blood $\mathrm{CD} 4+\mathrm{T}$ lymphocytes were quantified by flow cytometry using a commercially-available monoclonal antibodies (Beckman Coulter, Inc., Fullerton, CA).

\section{HIV-1 isolation}

Peripheral blood mononuclear cells (PBMCs) were obtained by centrifuging whole blood on a Ficoll-Hypaque density gradient. A total of $5 \times 10^{6}$ PBMCs were co-cultivated with $5 \times 10^{6}$ phytoemoagglutinin (PHA)-stimulated PBMCs from healthy seronegative donors in 5 ml of RPMI 1640 supplemented with $10 \%$ of Human IL-2, $10 \%$ of fetal bovine serum, glutamine $(2 \mathrm{nM}), 100 \mathrm{IU} / \mathrm{ml}$ penicillin and $100 \mu \mathrm{g} / \mathrm{ml}$ streptomycin. On the seventh day of culture and then twice weekly, supernatants were collected, stored at $-80^{\circ} \mathrm{C}$ and replaced with fresh medium. Cultures, placed in a humidified chamber at $37^{\circ} \mathrm{C}$ with $5 \% \mathrm{CO}_{2}$ air, were maintained for 27 days. Viral growth on cell culture was demonstrated by p24 antigen production using a commercially available kit (VIDAS HIV P24 II, Biomérieux, Marcy l'Etoile, France). A culture was considered positive if the concentration of p24 was higher than $5.0 \mathrm{pg} / \mathrm{ml}$. Positive supernatants were used for infecting $10^{6} \mathrm{MT}-2$ cells; cultures were maintained for 2 weeks, examined for syncytia twice a week and supernatant aliquots were stored at $-80^{\circ} \mathrm{C}$. Viral cultures with syncytium formation were defined as having a SI biological phenotype, whereas cultures without syncytium formation were defined as having a NSI biological phenotype. 


\section{$155 \quad$ V3 loop genotyping}

156 Using standard methods, HIV-1 proviral DNA and RNA were extracted from the 157 PBMC and plasma samples of all 36 patients, respectively, at time of virus isolation.

158 After cDNA was obtained from HIV-RNA by retrotranscription, the cDNA and proviral DNA ${ }_{2}^{1} 159$ from PBMCs were amplified by a nested PCR using outer primers MK603 (forward) $5^{\prime}$ 13 CAGAAAAATTGTGGGTCACAGTCTATTATGGGGTACCT 3' (HXB2 nt 6316-6353) and CD4R (reverse) 5' TATAATTCACTTCTCCAATTGTCC 3' (HXB2 nt 7675-7652), and inner primers: SQV2F1 (forward) 5' ACACATGCCTGTGTACCCACAGA 3' (HXB2 nt 6435-6457) and V3O2R (reverse) 5' ATTACAGTAGAAAAATTCCCCTCCAC 3' (HXB2 nt 7382-7357). A PCR product of 947 base pairs was obtained, including almost the entire gp120 from codon 43 of $\mathrm{C} 1$ to codon 2 of $\mathrm{V} 4$.

If no product was amplified, alternative first and second-round forward primers were employed: V3O2F (forward) 5' AATGTCAGYACAGTACAATGTACAC 3' (HXB2 nt 69456969) V3O2R (reverse) 5' ATTACAGTAGAAAAATTCCCCTCCAC 3' (HXB2 nt 7382-7357) as outer primers, and V3I2F (forward) 5' TAAATGGCAGTYTAGCAGAAGAAG 3' (HXB2 nt 7006-7029) V3I2R (reverse) 5' ACAATYTCTGGGTCCCCTCCTGAGGA 3' (HXB2 nt 7039-7314) as inner primers, thus obtaining a smaller PCR product of length $333 \mathrm{bp}$, including the V3 loop from codon 65 of $\mathrm{C} 2$ to codon 42 of $\mathrm{C} 3$.

PCR products were then sequenced in both $5^{\prime}$ and $3^{\prime}$ directions using the BigDye dye terminator cycle sequencing kit (Applied Biosystems, Foster City, CA) with primers V3O2F, V3O2R, V3I2F, V3I2R for gp120, and V3I2F and V3I2R for V3, and run on an ABI 310 automated sequencer.

A multiple alignment of patient sequences (GenBank accession numbers DQ984217DQ984276; DQ841560-DQ841561; DQ841564-DQ841567; DQ841569; FJ798215798302) with a reference alignment of the V3 region provided by the HIV sequence database of Los Alamos was obtained using Clustal W2. Only the alignment with the HxB2 
181 reference sequence has been reported; as sequence length ranged from 33 to 37 amino 182 acids (aa), gaps were inserted for sequences of a length $<37$ aa.

184 The Position-Specific Scoring Matrix PSSM method, freely available on the web 12185 (http://ubik.microbiol.washington.edu/computing/pssm/), was used arbitrarily for 13

\section{Statistical analysis}

For the purpose of this study, dual/mixed virus (X4/R5) were considered as X4.

Descriptive statistics were calculated for the demographic, clinical and virologicalimmunological characteristics of all cases. Mean and standard deviation (SD) are presented for normally distributed variables.

The Kruskall-Wallis test was utilized to compare quantitative variables, and Pearson's Chisquare test (Fisher exact test where appropriate) was used for categorical variables. The concordance between genotypic and phenotypic testing was analyzed by means of Kappa-statistics. Data analysis was performed with Epi InfoTM Version 3.4.3. 


\section{Results}

\section{Viro-immunological response to HAART}

Viro-immunological characteristics of patients in the study are shown in Table I. Naïve patients (pt 1-18) presented a mean CD4 count of $146.6 \pm 171.2$ and a mean plasma viral load $\log _{10} 5.1 \pm 0.9$ at baseline. In $17 / 18$ patients, a TAMs-sparing regimen based on abacavir or tenofovir plus lamivudine or emtricitabine was chosen, in combination with efavirenz in 2/18 patients and with a boosted PI in 16/18 patients; in one patient, T20 was also included in the first PI-based regimen. A total of $15 / 18$ patients achieved virological success (83\%); the median time to virological suppression was 3 months (range: 1 to 10 ). In three patients (pt 12, 15 and 16), plasma viral load was still detectable after 12 months, most likely due to a low adherence rate. In all patients, independent of viral suppression, a CD4 increase from baseline was observed, with a mean gain of CD4+ cells $/ \mathrm{mmc}$ equal to $173.4 \pm 139.1$.

Antiretroviral-experienced patients (pt 19 to 36 ) had a mean CD4 count of $174.3 \pm 149.7$ and a PVL of $4.9 \pm 0.9$ at time of failure; they were all NNRTI-experienced, and had been treated previously with a mean number of $5 \pm 1$ NRTIs and $4 \pm 1$ PIs, respectively; $7 / 18$ patients were also enfuvirtide-experienced. The mean length of previous antiretroviral therapy was $14 \pm 4$ years. All patients started a new antiretroviral regimen including boosted tipranavir; 11/18 patients were also treated with enfuvirtide. Patients 19-27 achieved virological success after a median time of three months (range 1 to 3 ); in this group of patients the mean CD4 increase after one year was $111.8 \pm 96.9$ cells. Patients 28 to $36 \mathrm{did}$ not respond to therapy and remained viremic; after a mean 12 month follow-up, the mean pVL was $4.81 \pm 0.7$; nevertheless, a mean CD4 count increase of $42.1 \pm 52.1$ was also obtained for these non-responder patients. 
The biological phenotype determined with MT-2 cell isolation (SI/NSI) and the predicted co-receptor use according to the V3 genotype for each patient are also shown in Table I. In 27/36 (75\%) patients, a concordant baseline V3 genotype was observed in plasma and PBMCs (Kappa agreement $=0.39$ ). In the plasma compartment, a X4 virus was noted in 9/36 (25\%) patients, three of whom were naïve (17\%) and six were experienced (33\%). The presence of a X4 variant did not correlate to any of the investigated clinical variables (gender, age, risk factor, CDC stage, baseline pVL). The CD4 nadir and the absolute number of CD4 cells at baseline, however, were lower in X4 patients, without a statistical significant difference between the two groups.

Also in the proviral DNA compartment where a total of $11 / 36$ (30.5\%) patients (six of whom were naïve and five were experienced patients) harboured a X4 genotype, no association was found with any clinical variable, including baseline CD4 cells/mmc and pVL.

$\mathrm{SI}$ isolates were cultured in five patients, only one of whom (pt 28) showed a complete agreement with the presence of a X4 genotype in both RNA and DNA. The overall concordance between MT-2 isolation and predicted co-receptor use based on RNA and DNA genotype was $69 \%(\mathrm{~K}=0.10)$ and $72 \%(\mathrm{~K}=0.23)$, respectively. An association between the presence of an $\mathrm{SI}$ isolate and a lower number of nadir $(36.8 \pm 34.1 \mathrm{cell} / \mathrm{mmc}$ in patients carrying SI viruses vs 162.4 cells/mmc \pm 164.5 in those carrying NSI viruses, $\mathrm{p}=0.03)$ and baseline CD4 cell count $(40.8 \pm 30.8$ cells $/ \mathrm{mmc}$ vs $179.7 \pm 163.2$ cells $/ \mathrm{mmc}$ in the two groups, respectively, $\mathrm{p}=0.05$ ) was described, while no correlation was found between SI phenotype and baseline pVL $\left(4.8 \pm 1.2 \log _{10} \mathrm{cp} / \mathrm{ml}\right.$ vs $5.0 \pm 0.9 \log _{10} \mathrm{cp} / \mathrm{ml}$, respectively, $p=0.9$ ).

In the group of experienced patients, the length of the previous treatment with antiretrovirals was not associated with the presence of SI variants at MT-2 isolation $(p=0.9)$ nor with X4 variants either in plasma RNA $(p=0.2)$ or in the proviral DNA $(p=0.9)$. 


\section{Association between baseline co-receptor usage and viro-immunological outcome}

The probability of achieving virological suppression after 12 months of therapy was not influenced by the presence of a X4 variant in plasma RNA (OR=1.23; $0.26-5,9895 \%$ IC; $\mathrm{p}=0.56)$ or PBMC DNA (OR=3. 00; $0.53-16,9095 \% \mathrm{IC} ; \mathrm{p}=0.19)$, nor by the presence of $\mathrm{SI}$ isolates at baseline $(\mathrm{OR}=0.27 ; 0.04-1.9295 \% \mathrm{IC} ; \mathrm{p}=0.19)$. In addition, the mean increase in CD4+ cells was similar for patients with a SI versus a NSI isolate $(p=0.30)$ and for patients with $\mathrm{X} 4$ versus a R5 variant in plasma $(p=0.47)$ or in PBMCs $(p=0.97)$; when considering the absolute number of CD4 cells/mmc at follow-up, the CD4+ count was significantly lower in patients with an SI isolate at baseline $(p<0.001)$.

\section{V3 genotype shift and response to HAART}

When analyzing the proviral DNA compartment, a total of $10 / 36(28 \%)$ patients $(6 / 18$ naïve and 4/18 experienced patients) switched their V3 genotype during the first 12 months of the new antiretroviral therapy (Table I); the env $\mathrm{V} 3$ sequences of these patients at baseline and at one-year follow-up are reported in Figure 1. In particular, in the naïve patient group, four subjects showed a shift from a X4 (pt 1-3) or X4/R5 (pt 4) to a R5 genotype after starting HAART. All these patients were virological responders and experienced a mean increase of $91 \pm 80 \mathrm{CD} 4 / \mathrm{mmc}$ during the course of therapy. Conversely, in two cases (pt 5 and 6), the emergence of a X4 genotype was described after 12 months of therapy, together with an undetectable viral load: also in this case an increase in the CD4 cell count was obtained (mean 132 \pm 49 CD4 cells/mmc). No changes in V3 genotype were observed for the three naïve patients (pt 12, 15 and 16) who did not reach viral suppression after one year of therapy, even if they all showed a pVL decrease in viral load $(-3,57,-1,69$, $3.47 \log _{10} \mathrm{cp} / \mathrm{ml}$, respectively). 
280 In the group of experienced patients, a X4 to R5 shift was described both in virological 281 responders (pt 19) and in non-responders (pt 28), while two virological responder patients 282 (pt 20 and 21) showed a reversion from a R5 to a X4 genotype.

Among non-responders, virus isolation and RNA genotyping were also performed; two cases of reversion from a SI to a NSI phenotype were observed with HAART which was confirmed in only one case by DNA genotyping. Lastly, in one case a change from an X4 to an R5 genotype was described only in RNA, but not in DNA or by virus isolation.

Overall, the lack of achieving virological suppression was not associated with a shift in proviral DNA from X4 to $\mathrm{R} 5(\mathrm{OR}=3,67 ; 0,37-35.995 \% \mathrm{IC}, \mathrm{p}=0.25)$ or from $\mathrm{R} 5$ to $\mathrm{X} 4$ (RR=1.3, 1.00-1.60 95\% IC, $p=0.14)$; time-to-viral-suppression was also similar in the two patient groups ( $p=0.9$ and 0.1 , respectively). No differences in terms of CD4 increase in both groups were observed ( $p=0.6$ and $p=0.2$, respectively)(Table II).

\section{Correlation between baseline patient characteristics and occurrence of a tropism} shift

The following baseline variables did not demonstrate any statistically significant association with a tropism shift in both directions: age, gender, CDC stage of infection, risk factor for HIV-1, previous exposure to antiretroviral therapy, length of previous HAART for the group of experienced patients, baseline CD4 count and pVL (Table II). On the contrary, a lower CD4 cell count nadir was associated with a greater probability of a R5 to X4 shift in the proviral compartment (mean CD4 nadir $27.2 \pm 30.6$ in shifting patients vs $161.6 \pm 150.6$ in patient not shifting $\mathrm{V} 3$ genotype, $\mathrm{p}=0.02$ ).

The presence of a discordant $\mathrm{V} 3$ genotype between RNA and DNA at baseline was not associated with a higher probability of shifting during therapy (OR=1.43; 0.28-7.30 95\% IC, 
1

$305 \mathrm{p}=0.49$ ). Also the total number of pol mutations associated with resistance in reverse

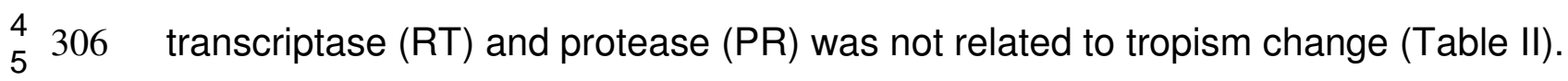

6

307 Lastly, the possible effect of including enfuvirtide in the new therapy on genotype shift was 8
9 308 investigated, but no association was found between use of enfuvirtide and presence of a 10 11 $12^{30}$ 13 1431 15 16 


\section{Discussion}

The env gene of HIV-1, which is directly exposed to host immunological pressure, is the most variable viral region. This variability influences the penetration of HIV-1 into different cell types, according to the two main chemokine co-receptor binding variants (X4 and R5) which are known to be correlated to diverse disease progression rates. However, the relationship between the prevalence of $\mathrm{X} 4$ and/or R5 strains in the viral quasispecies and the use of antiretroviral therapy requires further clarification. In fact, it is not known if HAART might facilitate the emergence of $X 4$ variants, as some reports seem to suggest [Johnston et al., 2003, Delobel et al., 2005], or whether the presence of X4 variants could hamper achievement of virological and immunological success [Brumme et al., 2004].

The aim of our study was to verify if tropism shift in both naïve and experienced patients is affected by HAART; thus, the evolution of the V3 genotype after 12 months of HAART was studied and compared in responder and non-responder patients.

Firstly, a varying frequency of X4 strains in naïve and antiretroviral experienced patient cohorts was described, illustrating a higher amount of X4 strains in experienced [Melby et al., 2006; Wilkin et al., 2007; Hunt et al., 2006; Coakley et al., 2006] than in naïve subjects [Brumme et al., 2005; Moyle et al., 2005; Demarest et al., 2004; Coakley et al., 2006. Poveda et al., 2007]. In fact, an association between the presence of $X 4$ variants and HAART had been noted in our previous study [Saracino et al., 2007]; in the present study, the prevalence of $X 4$ variants at baseline was similar in treated and naïve patients, the majority of whom, however, demonstrated an advanced stage of immunological impairment.

No statistically significant differences were observed in terms of mean CD4 increase nor probability of achieving virological suppression after starting or changing HAART between the two patient groups harboring a X4 or a R5 variant at baseline, respectively, even if patients carrying X4 variants at baseline had a decreased CD4 count, with a consequently 
reduced mean absolute number of CD4+ cells at follow-up. These results were comparable in naive and experienced patients, but the limited size of the sample did not permit definite conclusions; however, it must be emphasized that in no case was antiretroviral therapy success affected by the presence of a X4 strain in the viral mixture. Previous reports on the HOMER cohort suggested that the presence of $\mathrm{X} 4$ variants could be associated with a worse virological response, a finding, however, which was not confirmed by further analyses using co-receptor phenotype testing [Brumme et al., 2005]. Interestingly, and in contrast with earlier reports [Philpott et al., 2001; Equils et al., 2000; Skrabal et al., 2003; Galán et al., 2004; Johnston et al., 2003; Delobel et al., 2005], our study demonstrates that the V3 genotype shift is not influenced by HAART. In fact, a similar number of shifts was observed in both directions (from a X4 to an R5 or from a R5 to an $\mathrm{X} 4$ variant) during therapy in patients with homogeneous characteristics at baseline. This is in agreement with more recently published articles [Lwembe et al., 2009; Briz et al., 2008; Souliè et al., 2007] which also found that co-receptor switching is independent of HAART, while it is most likely affected by the rate of disease progression. Also the length of a previous HAART treatment in the group of experienced patients did not seem to influence the detection of a X4 variant at baseline or after therapy change in our population. No associations were found with the number of pol resistance associated mutations for NRTI, NNRTIs and PIs [Lehman et al., 2006], nor did the use of enfuvirtide correlate with a tropism change from baseline in our patient group, in contrast to data reported by Melby [Melby et al., 2006].

If the tropism shift is unrelated to HAART, the identification of other predictive factors for tropism change would be of great importance when treating with anti-CCR5 inhibitors; a shift between the testing for coreceptor tropism and the initiation of an anti-CCR5-based therapy is quite common, and might be associated to virological failure [Fätkenheuer et al., 2008]. The majority of baseline features investigated in our cohort, however, did not 
demonstrate a sufficient predictive power; in particular, the tropism shift was equally frequent among naïve patients initiating their first regimen and in previously-failed patients after therapy change, and did not seem to be associated with age, gender, clinical stage, modality of acquiring HIV-1 infection, and baseline viro-immunological parameters. Of note, however, the CD4 cell count nadir was associated to a R5-to- X4 tropism shift in our group of patients; if confirmed, this result which is in agreement with several reports which highlight the importance of immune impairment in the emergence of X4 variants, might be helpful for the selection of patients who would benefit from anti-CCR5 therapy and who most likely need to initiate therapy close to the time of screening.

Among the $5 / 6$ patients who switched from $X 4$ to R5 in DNA, five subjects already harbored R5 viruses in the plasma at baseline; therefore, the detection of a R5 strain after a one-year follow-up is probably due to the enrichment of the proviral reservoir by circulating viruses rather than by the ex-novo selection of new tropism variants. In some samples, the co-existence of both variants could have been underestimated for viral strains with a frequency below the sensitivity threshold (10-20\%) of the current PCR assays. This is an important limitation as these variants could eventually emerge during virological failure with CCR5-antagonist therapy; in the near future, studies based on the new ultra-deep sequencing techniques will permit the evaluation of the impact that these minority variants might have on clinical practice [Paredes and Clotet, 2009]. At present, direct sequencing on plasma and PBMC samples is currently accepted as an appropriate method due to its simplicity and acceptable correlation with clonal analysis [Delobel et al., 2007].

A reduced degree of concordance (Cohen's K statistics 0.39 ) was observed between the results obtained from the plasma and proviral DNA compartments in paired samples at baseline. In addition, the overall concordance between MT-2 isolation and predicted coreceptor use based on RNA (K=0.10) and DNA genotype ( $K=0.23)$ was low. Discrepancies 
between the two compartments were also noted by other researchers [Verhofstede $\mathrm{C}$ et al., 2009]; in a previous study, V3 analysis from plasma samples largely agreed with the corresponding DNA samples but greatly differed from the MT-2 biological phenotype [Saracino et al., 2007]. The differences existing between phenotypic (MT-2 isolation, coreceptor testing) and V3 genotype interpretation methods are not yet completely understood [Low et al., 2007, Garrido et al., 2008; Raymond et al., 2008; Saracino et al., 2007] although the validation of improved algorithms is ongoing [Poveda et al., 2009; Chueca et al., 2009] and must be considered when interpreting the results. However, it must be emphasized that in the current study, a closer association emerged between baseline immunological/clinical characteristics and the biological phenotype when compared to genotyping, thereby suggesting that, in the presence of a mixed viral population including X4R5 variants which are able to use both co-receptors, the finding of an $\mathrm{SI}$ isolate by the MT-2 cell assay clearly suggests the presence of a more aggressive virus. In fact, several reports indicate that co-receptor use and real cellular tropism are related, but distinct, whereas tropism reflects the ability of an isolate not only to enter, but also to replicate, in a particular target cell [Goodenow and Collman, 2006]. We acknowledge, however, the purely speculative value of these considerations due to the small sample size and to the lack of a comparison with a tropism assay.

In conclusion, in our cohort, the occurrence of a tropism shift both from an X4 to R5 or, on the contrary, from an R5 to a X4 variant was independent of HAART, irrespective of its efficacy. The tropism change in the proviral compartment during antiretroviral therapy could not be predicted from baseline patient features, with the exception of the CD4 cell count nadir which appeared to correlate with the occurrence of R5 to X4 shift. 


\section{ACKNOWLEDGMENTS}

413 We are grateful to Ms. Paulene Butts for the review of the manuscript and Gianfranco

414 Botte for secretarial assistance. 


\section{REFERENCES}

Berger EA, Murphy PM, Farber JM. 1999. Chemokine receptors as HIV-1 coreceptors: roles in viral entry, tropism, and disease. Annu Rev Immunol 17:657-700.

Brumme ZL, Dong WWY, Yipa B, Wynhovena B, Hoffman NG, Swanstrom R, Jensen MA, Mullins JI, Hogg RS, Montanera JSG, Harrigan PR. 2004. Clinical and immunological impact of HIV envelope V3 sequence variation after starting initial triple antiretroviral therapy. AIDS 18:F1-9.

Brumme ZL, Goodrich J, Mayer HB, Brumme CJ, Henrick BM, Wynhoven B, Asselin JJ, Cheung PK, Hogg RS, Montaner JSG, Harrigan PR. 2005. Molecular and Clinical Epidemiology of CXCR4-Using HIV-1 in a Large Population of Antiretroviral-Naive Individuals J Infect Dis 192:466-474.

Briz V, Poveda E, del Mar González M, Martín-Carbonero L, González-González R, Soriano V. 2008. Impact of antiretroviral therapy on viral tropism in HIV-infected patients followed longitudinally for over 5 years. J Antimicrob Chemother 61(2):405 -10.

Chueca N, Garrido C, Alvarez M, Poveda E, de Dios Luna J, Zahonero N, HernándezQuero J, Soriano V, Maroto C, de Mendoza C, García F. 2009. Improvement in the determination of HIV-1 tropism using the V3 gene sequence and a combination of bioinformatics tools. J Med Virol 81:763-7.

Coakley E, Benhamida J, Chappey, Whitcomb J, Goodrich J, van der Ryst E, Westby M, James I, Tressler R, Harrigan PR, Mayer H. 2006. An evaluation of tropism profiles and other characteristics among 3988 individuals screened for the A4001026, A4001027 (MOTIVATE 1) and A4001028 (MOTIVATE 2) phase 2b/3 studies of MARAVIROC, abstr. B. Second Int. Workshop Targeting HIV Entry, Boston, MA, 20 to 21 October 2006. Connor RI, Ho DD. 1994. Human immunodeficiency virus type 1 variants with increased replicative capacity develop during the asymptomatic stage before disease progression. $\mathrm{J}$ 440 Virol 68: 4400-08. 
441 Daar ES, Kesler KL, Petropoulos CJ, Huang W, Bates M, Lail AE, Coakley EP, Gomperts 442 ED, Donfield SM. Hemophilia Growth and Development Study. 2007. Baseline HIV type 1 443 coreceptor tropism predicts disease progression. Clin Infect Dis 1;45 (5):643-9.

Delobel P, Sandres-Sauné K, Cazabat M, Pasquier C, Marchou B, Massip P, Izopet J. 2005. R5 to X4 switch of the predominant HIV-1 population in cellular reservoirs during effective highly active antiretroviral therapy. J Acquir Immune Defic Syndr 38 (4):382-392.

Delobel P, Nugeyre MT, Cazabat M, Sandres-Sauné K, Pasquier C, Cuzin L, Marchou B, Massip P, Cheynier R, Barré-Sinoussi F, Izopet J, Israël N. 2006. Naive T-cell depletion related to infection by X4 HIV-1 in poor immunological responders to HAART. J Virol 80 (20):10229-10236.

Delobel P, Nugeyre MT, Cazabat M, Pasquier C, Marchou B, Massip P, Barre-Sinoussi F, Israël N, Izopet J. 2007. Population-based sequencing of the V3 region of env for predicting the coreceptor usage of human immunodeficiency virus type 1 quasispecies. $\mathrm{J}$ Clin Microbiol 45(5):1572-1580.

Demarest J, Bonny T, Vavaro C,LaBranche C,Kitrinos K, McDanal C,Sparks S, Chavers S, Castillo S,Elrick D, McCarty D, Whitcomb J,Huang W, Petropoulos C, Piscitelli S. 2004. HIV-1 co-receptor tropism in treatment naive and experienced subjects, abstr. $\mathrm{H}-1136.44^{\text {th }}$ Intersci. Conf. Antimicrob. Agents Chemother., Washington, DC, 30 October to 2 November 2004.

Deng H, Deng H, Liu R, Ellmeier W, Choe S, Unutmaz D, Burkhart M, Di Marzio P, Marmon S, Sutton RE, Hill CM, Davis CB, Peiper SC, Schall TJ, Littman DR, Landau NR. 1996. Identification of a major co-receptor for primary isolates of HIV-1. Nature 381:66166.

de Jong JJ, De Ronde A, Keulen W, Tersmette M, Goudsmit J. 1992. Minimal requirements for the human immunodeficiency virus type $1 \mathrm{~V} 3$ domain to support the 
syncytium-inducing phenotype: analysis by single amino acid substitution. J Virol 66(11):6777-6780.

de Roda HAM, Koot M, Cornelissen M, Keet IP, Brouwer M, Broersen SM, Bakker M, Roos MT, Prins M, de Wolf F, Coutinho RA, Miedema F, Goudsmit J, Schuitemaker H. 1997. Association between CCR5 genotype and the clinical course of HIV-1 infection. Ann Intern Med 127:882-890.

Equils O, Garratty E, Wei LS, Plaeger S, Tapia M, Deville J, Krogstad P, Sim MS, Nielsen K, Bryson YJ. 2000. Recovery of replication competent virus from CD4 T cell reservoirs and change in co-receptor use in HIV-1-infected children responding to HAART. J Infect Dis 182:751-7.

Fätkenheuer G, Nelson M, Lazzarin A, Konourina I, Hoepelman AI, Lampiris H, Hirschel B, Tebas P, Raffi F, Trottier B, Bellos N, Saag M, Cooper DA, Westby M, Tawadrous M, Sullivan JF, Ridgway C, Dunne MW, Felstead S, Mayer H, van der Ryst E; MOTIVATE 1 and MOTIVATE 2 Study Teams. 2008. Subgroup analyses of maraviroc in previously treated R5 HIV-1 infection. N Engl J Med 2;359 (14):1442-55.

Fouchier RA, Brouwer M, Broersen SM, Schuitemaker H. 1995. Simple determination of human immunodeficiency virus type 1 syncitium inducing V3 genotype by PCR. J Clin Microbiol 33:906-911.

Galán I, Jiménez JL, González-Rivera M., De José MI, Navarro ML, Ramos JT, Mellado MJ, Gurbindo MD, Bellón JM, Resino S, Cabrero E, Muñoz-Fernández MA. 2004. Virological phenotype switches under salvage therapy with lopinavir-ritonavir in heavily pretreated HIV-1 vertically infected children. AIDS 23;18(2):247-55.

Garrido C, Roulet V, Chueca N, Poveda E, Aguilera A, Skrabal K, Zahonero N, Carlos S, García F, Faudon JL, Soriano V, de Mendoza C. 2008. Evaluation of eight different bioinformatics tools to predict viral tropism in different human immunodeficiency virus type 1 subtypes. J Clin Microbiol 46(3):887-91. 
492 Goodenow MM, Collman RG. 2006. HIV-1 coreceptor preference is distinct from target cell 493 tropism: a dual-parameter nomenclature to define viral phenotypes. J Leukoc Biol 494 80(5):965-972.

Hunt PW, Harrigan PR, Huang W, Bates M, Williamson DW, McCune JM, Price RW, Spudich SS, Lampiris H, Hoh R, Leigler T, Martin JN, Deeks SG. Harrigan PR. 2006. Prevalence of CXCR4 Tropism among Antiretroviral-Treated HIV-1-Infected Patients with Detectable Viremia. J Infect Dis 194:926-930.

Jensen MA, Li FS, van 't Wout AB, Nickle DC, Shriner D, He HX, McLaughlin S, Shankarappa R, Margolick JB, Mullins JI. 2003. Improved coreceptor usage prediction and genotypic monitoring of R5-to-X4 transition by motif analysis of human immunodeficiency virus type 1 env V3 loop sequences. J Virol 77(24), 13376-88.

Johnston ER, Zijenah LS, Mutetwa S, Kantor R, Kittinunvorakoon C, Katzenstein DA. 2003. High frequency of syncytium-inducing and CXCR4-tropic viruses among human immunodeficiency virus type 1 subtype C-infected patients receiving antiretroviral treatment. J Virol 77(13):7682-8.

Karlsson A, Parsmyr K, Sandstrom E, Fenyo EM, Albert J. 1994. MT-2 cell tropism as prognostic marker for disease progression in human immunodeficiency virus type 1 infection. J Clin Microbiol 32:364-370.

Lehmann C, Däumer M, Boussaad I, Sing T, Beerenwinkel N, Lengauer T, Schmeisser N, Wyen C, Fätkenheuer G, Kaiser R. 2006. Stable coreceptor usage of HIV in patients with ongoing treatment failure on HAART. J Clin Virol 37(4):300-4.

Low AJ, Dong W, Chan D, Sing T, Swanstrom R, Jensen M, Pillai S, Good B, Harrigan PR. 2007. Current V3 genotyping algorithms are inadequate for predicting X4 co-receptor usage in clinical isolates. AIDS 12;21(14):F17-24.

Lwembe R, Lihana RW, Ochieng' W, Panikulam A, Mongoina CO, Palakudy T, de Koning $H$, Ishizaki A, Kageyama S, Musoke R, Owens M, Songok EM, Okoth FA, Ichimura H, 
2009. Changes in the HIV Type 1 Envelope Gene from Non-Subtype B HIV Type 1Infected Children in Kenya. AIDS Res Hum Retrovir 25 (2):141-7.

Maas JJ, Gange SJ, Schuitemaker H, Coutinho RA, van Leeuwen R, Margolick JB. 2000.

Strong association between failure of $T$ cell homeostasis and the syncytium-inducing phenotype among HIV-1-infected men in the Amsterdam Cohort Study. AIDS 14:11551161.

Melby T, Despirito M, Demasi R, Heilek-Snyder G, Greenberg ML, Graham N. 2006. HIV-1 Coreceptor Use in Triple-Class Treatment-Experienced Patients: Baseline Prevalence, Correlates, and Relationship to Enfuvirtide Response. J Infect Dis 194:238-246.

Moore JP, Kitchen SG, Pugach P, Zack JA. 2004. The CCR5 and CXCR4 coreceptors Central to understanding the transmission and pathogenesis of HIV-1 infection. AIDS Res Hum Retrov 20:111-126.

Moyle GJ, Wildfire A, Mandalia S, Mayer H, Goodrich J, Whitcomb J, Gazzard BG. 2005. Epidemiology and Predictive Factors for Chemokine Receptor Use in HIV-1 Infection. J Infect Dis 191:866-872.

Paredes R, Clotet B. HIV Drug Resistance testing. 2008. http://www.touchinfectionus-eudigital.com/euinfectious/vol2iss2/template (accessed 20/02/2009).

Philpott S, Weiser B, Anastos K, Kitchen CM, Robison E, Meyer WA 3rd, Sacks HS, Mathur-Wagh U, Brunner C, Burger H. 2001. Preferential suppression of CXCR4-specific strains of HIV-1 by antiviral therapy. J Clin Invest 107:431-438.

Poveda E, Briz V, de Mendoza C, Benito JM, Corral A, Zahonero N, Lozano S, GonzálezLahoz J, Soriano V. 2007. Prevalence of X4 Tropic HIV-1 Variants in Patients With Differences in Disease Stage and Exposure to Antiretroviral Therapy. J Med Virol 79:10401046.

Poveda E, Seclén E, González Mdel M, García F, Chueca N, Aguilera A, Rodríguez JJ, González-Lahoz J, Soriano V. 2009. Design and validation of new genotypic tools for 
easy and reliable estimation of HIV tropism before using CCR5 antagonists. JAC 63:1006-10.

Raymond S, Delobel P, Mavigner M, Cazabat M, Souyris C, Sandres-Sauné K, Cuzin L, Marchou B, Massip P, Izopet J. 2008. Correlation between genotypic predictions based on V3 sequences and phenotypic determination of HIV-1 tropism. AIDS 12; 22 (14): F11- 6.

Saracino A, Monno L, Punzi G, Cibelli DC, Tartaglia A, Scudeller L, Brindicci G, Lagioia A, Scotto G, Angarano G. 2007. HIV-1 biological phenotype and predicted co-receptor usage based on V3 loop sequence in paired PBMC and plasma samples. Virus Res 130:34-42.

Schuitemaker H, Kootstra NA, de Goede RE, de Wolf F, Miedema F, Tersmette M. 1991. Monocytotropic human immunodeficiency virus type 1 (HIV-1) variants detectable in all stages of HIV-1 infection lack T-cell line tropism and syncitium-inducing ability in primary T-cell culture. J Virol 65:356-363.

Skrabal K, Trouplin V, Labrosse B, Obry V, Damond F, Hance AJ, Clavel F, Mammano F. 2003. Impact of antiretroviral treatment on the tropism of HIV-1 plasma virus populations. AIDS 17:809-814.

Soulié C, Marcelin AG, Ghosn J, Amellal B, Assoumou L, Lambert S, Duvivier C, Costagliola D, Katlama C, Calvez V. 2007. HIV-1 X4/R5 co-receptor in viral reservoir during suppressive HAART. AIDS 21:2243-2250.

Verhofstede C, Vandekerckhove L, Eygen VV, Demecheleer E, Vandenbroucke I, Winters B, Plum J, Vogelaers D, Stuyver L. 2009. CXCR4-using HIV type 1 variants are more commonly found in peripheral blood mononuclear cell DNA than in plasma RNA. J Acquir Immune Defic Syndr 1;50(2):126-36.

Waters L, Mandalia S, Randell P, Wildfire A, Gazzard B, Moyle G. 2008. The impact of HIV tropism on decreases in CD4 cell count, clinical progression, and subsequent response to a first antiretroviral therapy regimen. Clin Infect Dis 15;46(10):1617-23. 
2569 Whitcomb JM, Huang W, Fransen S, Limoli K, Toma J, Wrin T, Chappey C, Kiss LD, 4
5 570 Paxinos EE, Petropoulos CJ. 2007. Development and characterization of a novel single6 7571 cycle recombinant virus assay to determine HIV-1 coreceptor tropism. Antimicrob Agents 8

9572 Chemother 51:566-575.

12573 Wilkin TJ, Su Z, Kuritzkes DR, Hughes M, Flexner C, Gross R, Coakley E, Greaves W, 13

Godfrey C, Skolnik PR, Timpone J, Rodriguez B, Gulick RM. 2007. HIV Type 1 Chemokine ${ }_{17}^{16} 575$ Coreceptor Use among Antiretroviral Experienced Patients Screened for a Clinical Trial of 18

a CCR5 Inhibitor: AIDS Clinical Trial Group A5211 Clin Infect Dis 44:591-595. 